Article

\title{
Synthesis and Phytotoxic Activity of New Pyridones Derived from 4-Hydroxy-6-Methylpyridin-2(1H)-one
}

\author{
Antonio Jacinto Demuner ${ }^{1}$, Vania Maria Moreira Valente ${ }^{1}$, Luiz Cláudio Almeida Barbosa ${ }^{1,2, *}$, \\ Akshat H. Rathi ${ }^{2}$, Timothy J. Donohoe ${ }^{2}$ and Amber L. Thompson ${ }^{2}$ \\ Department of Chemistry, Federal University of Vicosa, Av. P. H. Rolfs, s/n, 36570-000, Vicosa, \\ MG, Brazil; E-Mails: ademuner@ufv.br (A.J.D.); vvalente@ufv.br (V.M.M.V.) \\ 2 Department of Chemistry, University of Oxford, 12 Mansfield Road, Oxford OX1 3TA, UK; \\ E-Mails: akshat.rathi@chem.ox.ac.uk (A.H.R.); timothy.donohoe@chem.ox.ac.uk (T.J.D.); \\ amber.thompson@chem.ox.ac.uk (A.L.T.)
}

* Author to whom correspondence should be addressed; E-Mail: 1cab@ufv.br.

Received: 5 November 2009; in revised form: 24 November 2009 / Accepted: 30 November 2009 / Published: 1 December 2009

\begin{abstract}
Commercial dehydroacetic acid was converted into 4-hydroxy-6-methylpyridin2(1H)-one (3), which was then condensed with several aliphatic aldehydes to produce seven new title compounds in variable yields (35-92\%). Reaction of 3 with $\alpha, \beta$-unsaturated aldehydes resulted in the formation of condensed pyran derivatives $\mathbf{4 g}$ ' and $\mathbf{4 h}$ '. A mechanism is proposed to explain the formation of such compounds. The effects of all methylpyridin2(1H)-one derivatives on the development of the dicotyledonous species Ipomoea grandifolia and Cucumis sativus and the monocotyledonous species Sorghum bicolor were evaluated. At the dose of $6.7 \times 10^{-8} \mathrm{~mol}$ a.i./g substrate the compounds showed some phytotoxic selectivity, being more active against the dicotyledonous species. These compounds can be used as lead structures for the development of more active phytotoxic products.
\end{abstract}

Keywords: pyridine; x-ray; phytotoxicity; weeds; herbicides

\section{Introduction}

Pyridin-2(1H)-ones are known to possess a range of biological activities such as analgesic, antifungal, antimalarial, antiinflammatory, antibacterial, anti-HIV, phytotoxic, antitumoral and 
antiviral properties [1-9]. Functionalized pyridin-2(1H)-ones have been used as versatile intermediates in the synthesis of a wide range of nitrogen-containing heterocycles, such as pyridine, quinolizidine, and indolizidine alkaloids [10,11]. Fluridone and sapinopyridione are representative examples of pyridinones that possess phytotoxic activity [5,7]. This class of compounds has been used to formulate lead compounds for the synthesis of new pyridiones $[1,3,4,12,13]$, including the bis(pyridyl)methanes, which present antitumoral activity [8,9]. Recently, we have been utilizing natural products as models for the development of new compounds with phytotoxic activity [14-24]. In continuing our research in this direction, we now report the synthesis of pyridone derivatives $\mathbf{4 a - h}$ and some studies on their phytotoxic activities.

\section{Results and Discussion}

\subsection{Synthesis of bis-pyridones}

The hydrolysis of dehydroacetic acid 1 [25] with sulfuric acid afforded compound 2 in $86 \%$ yield. Compound 2 was then reacted with aqueous ammonium hydroxide to produce the corresponding pyridone 3 in $80 \%$ yield. Treatment of $\mathbf{3}$ under basic conditions in the presence of several aldehydes resulted in the condensed compounds $\mathbf{4 a - h}$ in variable yields (Scheme 1).

Scheme 1. Reagents and conditions for the synthesis of pyridones $\mathbf{4 a - h}$.

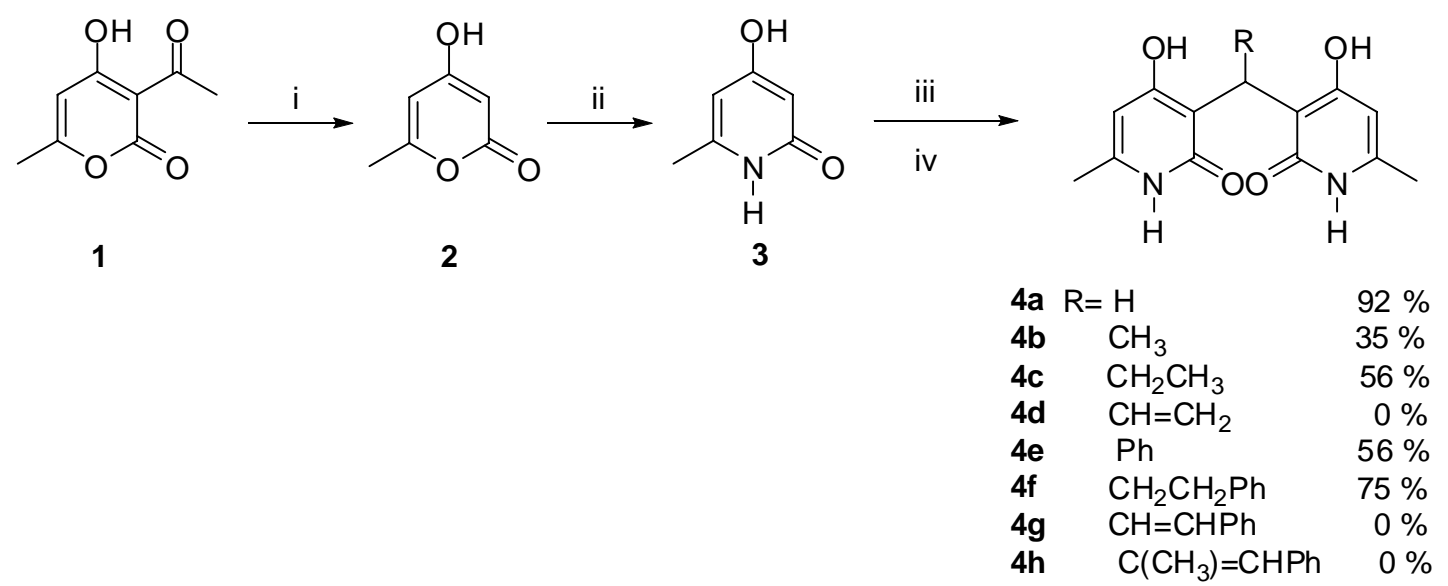

Reagents and conditions: i) $\mathrm{H}_{2} \mathrm{SO}_{4} 92 \%$ (5 eq), $130{ }^{\circ} \mathrm{C}, 10$ minutes, $86 \%$. ii) $\mathrm{NH}_{4} \mathrm{OH}$ (aq) (5 eq), $100{ }^{\circ} \mathrm{C}, 6 \mathrm{~h}, 80 \%$. iii) compound $3(2 \mathrm{eq})$, ethanol $/$ methanol $(1: 1 \mathrm{v} / \mathrm{v})$, piperidine $(0.15 \mathrm{eq})$, pyridine (0.55 eq), $25^{\circ} \mathrm{C}$. iv) $\mathrm{RCHO}(1 \mathrm{eq})$.

It was found that formaldehyde reacted very quickly and efficiently, resulting in a $92 \%$ yield of the condensed bis-pyridone 4a. In the cases of acetaldehyde and propanaldehyde the reactions were not clean, giving the desired condensation compounds in much lower yields $(4 \mathbf{b}, 35 \% ; 4 \mathbf{c}, 56 \%)$ and several side products were observed by TLC analysis of the crude reaction mixtures. To study the influence on the biological activity of an unsaturated group at the methine carbon, acrolein was reacted with compound 3 under the same conditions described. In this case the required bis-pyridone was not isolated and only polymerized compounds were detect by ESI-MS and NMR of the crude reaction mixture. 
In order to further explore the Structure Activity Relationships (SAR), the preparation of condensed bis-pyridone containing aromatic groups linked to the methine carbon bridge was attempted. Thus, the reaction of benzaldehyde and 2-phenylpropanaldehyde with 3 resulted in the formation of the corresponding bis-pyridones $4 \mathbf{e}$ and $\mathbf{4 f}$ in $56 \%$ and $75 \%$ yields, respectively. The structures of all condensed products were determined by spectroscopic analysis. In the case of compound $\mathbf{4 f}$, the structure was also determined by X-ray analysis (Figure 1).

Figure 1. Single crystal structure of compound 4f. Atomic displacement parameters shown at $50 \%$ probability and the disorder are omitted for clarity.

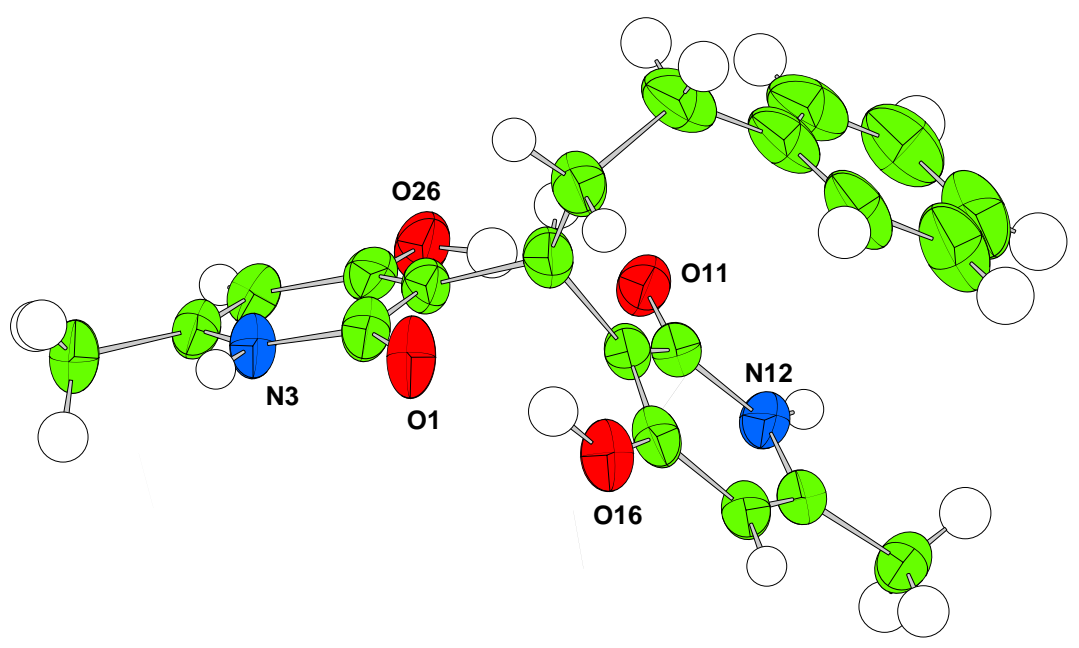

Unexpectedly the reaction of pyridione 3 with cinnamaldehyde and $(E)$-2-methylcinnamaldehyde did not give the desired condensed products. In case of the cinnamaldehyde adduct the HR-MS showed a peak at $m / z=387.1301$, corresponding to the molecular formula $\mathrm{C}_{21} \mathrm{H}_{20} \mathrm{NaN}_{2} \mathrm{O}_{4}$. The ${ }^{13} \mathrm{C}$-NMR spectrum showed signals corresponding to two $\mathrm{CH}_{3}$, one $\mathrm{CH}_{2}$, six $\mathrm{CH}$, two $\mathrm{C}=\mathrm{O}$ and seven non-hydrogenated carbons. For the $(E)$-2-methylcinnamaldehyde adduct, the product isolated as a white solid with HR-MS showed a peak at $\mathrm{m} / z=276.0095$ corresponding to the molecular formula $\mathrm{C}_{16} \mathrm{H}_{15} \mathrm{NaNO}_{2}$. The ${ }^{13} \mathrm{C}$-NMR spectrum showed signals corresponding to two $\mathrm{CH}_{3}$, six $\mathrm{CH}$, one $\mathrm{C}=\mathrm{O}$ and five non-hydrogenated carbons. Single crystal diffraction data were collected for both $\mathbf{4 g}$ ' and $\mathbf{4 h}$ ' yielding the structures shown in Scheme 2 and Figures 2 and 3. Both compounds were formed as a racemic mixture. Formation of a compound similar to $\mathbf{4 h}$ ' has been reported by Lee et al. [26], however in none of the published examples a compound with the structure of $\mathbf{4} \mathbf{g}$ ' was observed.

Although no mechanistic investigation was carried out, a pathway is proposed that leads to the formation of $\mathbf{4 g}$ ' and $\mathbf{4 h}$ ' (Scheme 2). Initially, an aldol condensation of pyridone 3 with cinnamaldehyde results in the intermediate (a). Depending on the nature of the $\mathrm{R}$ group $\left(\mathrm{H}\right.$ or $\left.\mathrm{CH}_{3}\right)$ the product formed in the next step is different. In case of cinnamaldehyde a 1,6-addition of a second molecule of the pyridone resulting in the intermediate (c) occurs. This intermediate can be in equilibrium with (d), which under basic conditions cyclises to yield 4g'. In case of (E)-2-methylcinnamaldehyde, steric hindrance involving the methyl group and the oxygen favors the formation of (b). This intermediate then undergoes a 3,3-sigmatropic rearrangement to give $\mathbf{4 h}$ '. This rearrangement ensures that a second addition is impossible. At this point we should observe that 
according to the proposed mechanism a concentration of pyridine could have some influence on the results of the reactions, leading to different products, but this is open to further investigation.

Scheme 2. Proposed mechanism for formation of $\mathbf{4 g}$ ' and $\mathbf{4 h}$ '.<smiles></smiles>

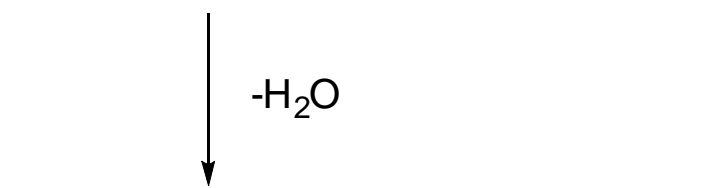<smiles>[R]C(=C[PH2+])/C=C1/C(=O)C=C(C)N([Tl])C1=O</smiles><smiles>C1=CC1</smiles><smiles>[R]C(C=Cc1ccccc1)=CC=C1C(=O)C=C(C)NC1=O</smiles>

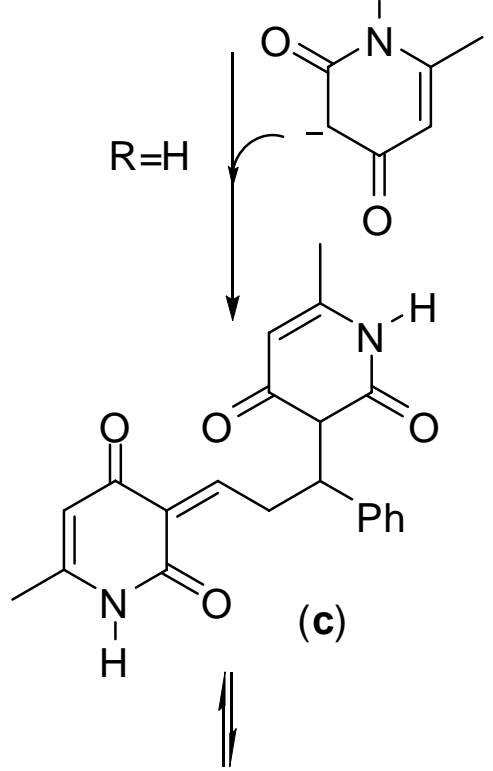
$\downarrow \mathrm{R}=\mathrm{CH}_{3}$<smiles>[B]CCC1C(=O)C=C(C)NC1=CCC(c1ccccc1)c1c(O)[nH]c(C)cc1=O</smiles><smiles>Cc1cc(O)c(C2CC(c3ccccc3)c3c(cc(C)[nH]c3=O)O2)c(=O)[nH]1</smiles> 
Figure 2. Single crystal structure of compound 4g'. Atomic displacement parameters shown at 50\% probability, one equivalent and the disordered DMSO are omitted for clarity.

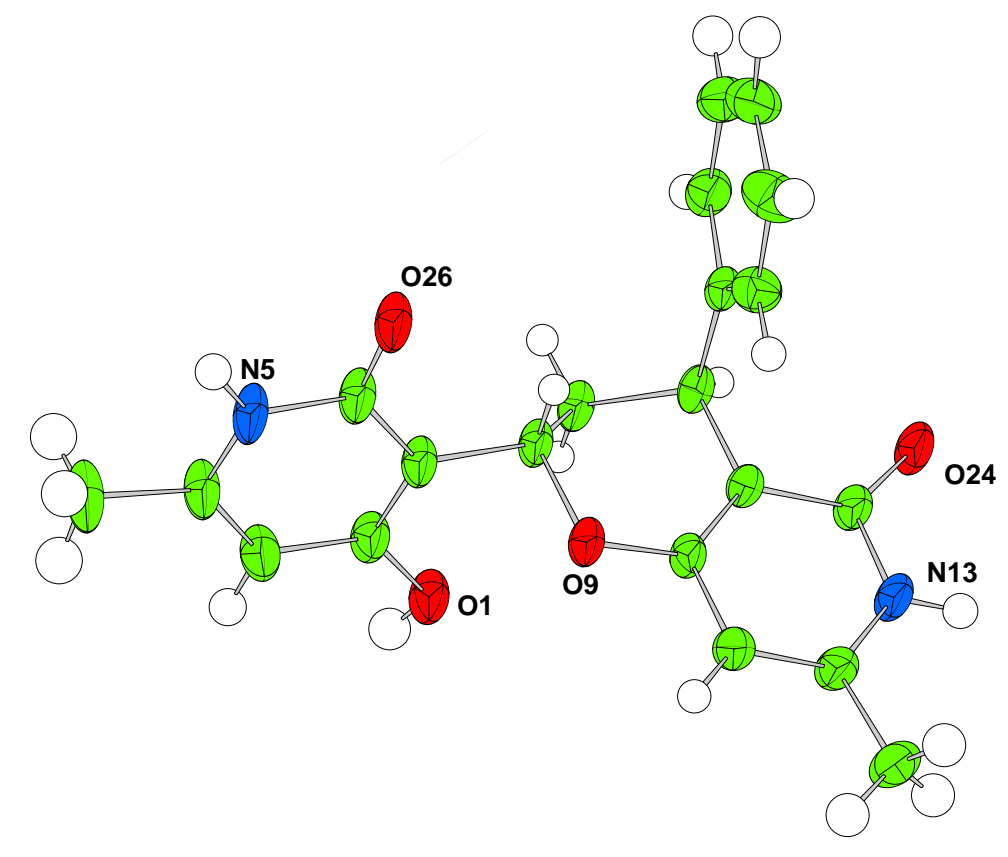

Figure 3. Single crystal structure of $\mathbf{4 h}$ ' showing the hydrogen bonding amide dimer. Atomic displacement parameters are shown at 50\% probability.

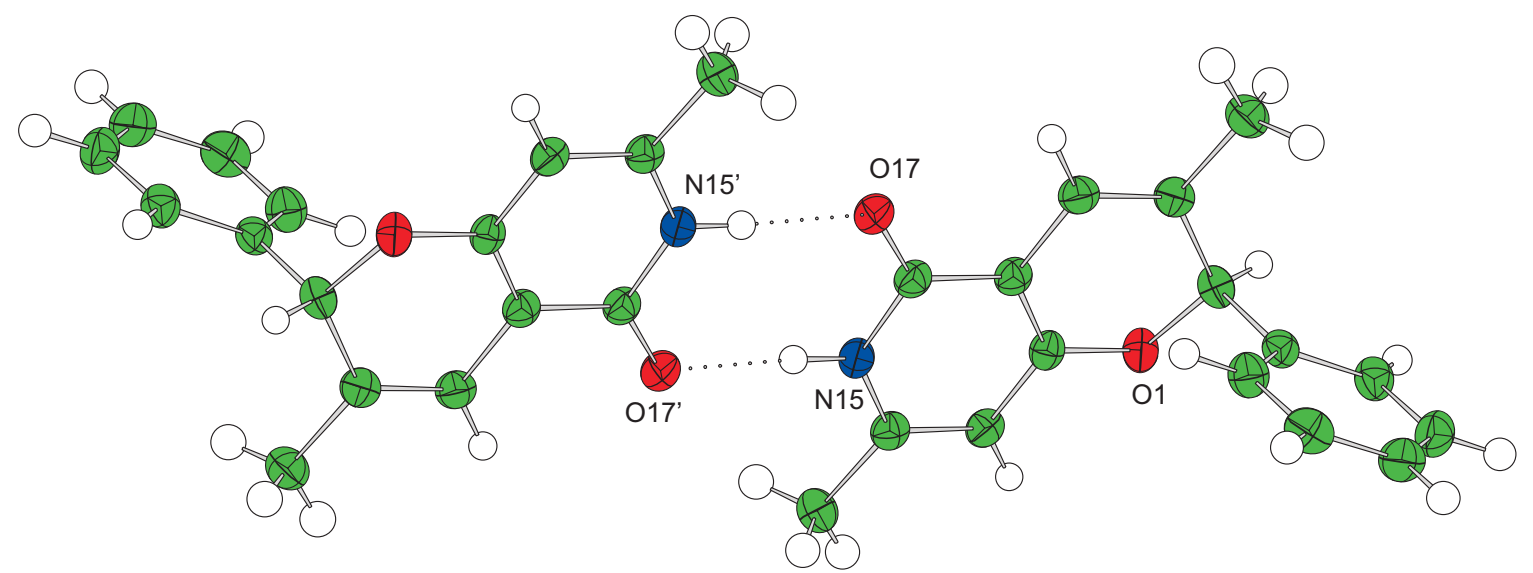

\subsection{Phytotoxicity assay}

All the compounds were evaluated against S. bicolor, C. sativus and I. grandifolia, using sand as a substrate. Although the compounds could have different adsorption properties on sand and this could affect the biological activity, this aspect was beyond the scope of the current work. The effect of compounds $\mathbf{4 a - c}$, 4e-f, $\mathbf{4 g}$ ' and $\mathbf{4 h}$ ' on the radicle growth of Sorghum bicolor and Cucumis sativus was evaluated at $5 \times 10^{-4} \mathrm{~mol} \mathrm{~L}^{-1}$ concentration (Table 1). All the compounds caused less than $50 \%$ inhibition of both tested plants. The most active compounds were $\mathbf{4} \mathbf{g}^{\prime}$ and $\mathbf{4 h}$, should be causing around $45 \%$ inhibition of the root growth of $S$. bicolor and C. sativus. 
Table 1. Effects of compounds $4 \mathbf{a}-\mathbf{c}$ and $\mathbf{4 e - h}\left(5 \times 10^{-4} \mathrm{~mol} \mathrm{~L}{ }^{-1}\right)$ on the radicle growth of $S$. bicolor and C. sativus seedlings after 72 hours.

\begin{tabular}{|c|c|c|}
\hline Compound & $\begin{array}{c}\text { C. sativus } \\
\text { inhibition (\%)* }\end{array}$ & $\begin{array}{c}\text { S. bicolor } \\
\text { inhibition (\%) }\end{array}$ \\
\hline $\mathbf{4 a}$ & $27.6 \mathrm{Ca}$ & $27.1 \mathrm{Ba}$ \\
$\mathbf{4 b}$ & $31.2 \mathrm{BCa}$ & $23.9 \mathrm{Ba}$ \\
$\mathbf{4 c}$ & $30.2 \mathrm{BCa}$ & $26.9 \mathrm{Ba}$ \\
$\mathbf{4 e}$ & $36.5 \mathrm{ABCa}$ & $18.9 \mathrm{Bb}$ \\
$\mathbf{4 f}$ & $38.5 \mathrm{ABCa}$ & $25.0 \mathrm{Bb}$ \\
$\mathbf{4 g}$ & $41.0 \mathrm{ABa}$ & $44.3 \mathrm{Aa}$ \\
$\mathbf{4 h}$ & $45.3 \mathrm{Aa}$ & $44.3 \mathrm{Aa}$ \\
\hline
\end{tabular}

* Mean values in the same column with the same capital letters are not significant at $\mathrm{P}=0.05 \%$ by Tukey's test; Mean values in the same line with the same small letter are not significant at $\mathrm{P}=0.05 \%$ by Tukey's test.

Once all compounds showed some activity on the Petri dish test they were submitted to a 21 day assay in a greenhouse using S. bicolor, C. sativus and the weed Ipomoea grandifolia as test plants (Table 2).

Table 2. Effect of compounds $\mathbf{4 a - c}$, e-h $\left(6.7 \times 10^{-8} \mathrm{~mol}\right.$ a.i./g substrate $)$ on the biomass production of radicle growth of $S$. bicolor and C. sativus seedlings after 21 days.

\begin{tabular}{cllllll}
\hline & \multicolumn{2}{c}{ S. bicolor } & \multicolumn{2}{c}{ C. sativus } & \multicolumn{2}{c}{ I. grandifolia } \\
\cline { 2 - 7 }- & aerial part* & roots & aerial part & roots & aerial part & roots \\
\hline $\mathbf{4 a}$ & $22.3 \mathrm{CDc}$ & $37.4 \mathrm{ABb}$ & $42.6 \mathrm{Bb}$ & $65.0 \mathrm{BCa}$ & $64.4 \mathrm{Aa}$ & $38.6 \mathrm{DEb}$ \\
$\mathbf{4 b}$ & $31.8 \mathrm{BCc}$ & $48.0 \mathrm{Ab}$ & $63.7 \mathrm{Aa}$ & $80.8 \mathrm{Aa}$ & $49.8 \mathrm{Bb}$ & $45.5 \mathrm{CDb}$ \\
$\mathbf{4 c}$ & $51.6 \mathrm{Ab}$ & $44.2 \mathrm{Ab}$ & $63.5 \mathrm{Aa}$ & $63.9 \mathrm{BCa}$ & $68.4 \mathrm{Aa}$ & $72.8 \mathrm{Aa}$ \\
$\mathbf{4 e}$ & $18.1 \mathrm{Db}$ & $31.7 \mathrm{Bb}$ & $34.9 \mathrm{BCa}$ & $67.5 \mathrm{BCa}$ & $32.8 \mathrm{Ca}$ & $32.8 \mathrm{~Eb}$ \\
$\mathbf{4 f}$ & $40.2 \mathrm{ABa}$ & $38.6 \mathrm{ABb}$ & $38.7 \mathrm{BCa}$ & $57.6 \mathrm{Ca}$ & $45.6 \mathrm{BCa}$ & $44.3 \mathrm{CDEb}$ \\
$\mathbf{4 g}$ & $42.7 \mathrm{ABb}$ & $46.8 \mathrm{Ac}$ & $38.6 \mathrm{BCb}$ & $74.5 \mathrm{ABa}$ & $56.8 \mathrm{ABa}$ & $58.2 \mathrm{Bb}$ \\
$\mathbf{4 h}$ & $38.1 \mathrm{Bb}$ & $42.8 \mathrm{ABb}$ & $27.5 \mathrm{Cc}$ & $63.8 \mathrm{BCa}$ & $49.3 \mathrm{Ba}$ & $55.3 \mathrm{BCa}$ \\
\hline
\end{tabular}

* Mean values in the same column with the same capital letters are not significant at $\mathrm{P}=0.05 \%$ by Tukey's test; Mean values in the same line with the same small letter are not significant at $\mathrm{P}=$ $0.05 \%$ by Tukey's test.

In the case of $S$. bicolor compounds $\mathbf{4 c}$, $\mathbf{4 f}$ and $\mathbf{4 g}$ ' caused higher inhibitory effect on the development of the aerial parts $(51.6 \%, 40.2 \%$ and $42.7 \%$, respectively). On the other hand, $4 \mathbf{b}, \mathbf{4 c}$, and $\mathbf{4 g}$ ' caused greatest root inhibition development (48.0\%, 44.2\% and 46.8\%, respectively). The results observed for compound $\mathbf{4 g}$ ' confirm its higher activity found in the Petri dish test in relation to the other compounds.

For $C$. sativus, a dicotyledonous species, compounds $\mathbf{4 b}$ and $\mathbf{4 c}$ most severely inhibited the development of the aerial parts (63.7\% and $63.5 \%$, respectively). All the other compounds, including the pyrans $\mathbf{4}$ ' ' and $\mathbf{4 h}$ ', caused less than $50 \%$ inhibition on the aerial parts. The development of the roots of $C$. sativus was most affected by compounds $\mathbf{4 b}(80.8 \%$ inhibition) and $\mathbf{4 g} \mathbf{g}(74.5 \%)$. All the 
other compounds were also very active against this dicotyledonous species, causing increases inhibition of the development of their roots compared to the aerial parts.

Having confirmed the phytotoxicity of the pyridone derivatives against the monocotyledon and dicotyledonous test species, their effect on the development of the important dicotyledonous weed species I. grandifolia were also evaluated. For this species, compounds $\mathbf{4 a}$, $\mathbf{4 c}$ and $\mathbf{4 g}$ ' inhibited the development of the aerial part by $64.4 \%, 68.4 \%$ and $56.8 \%$, respectively. Compound $4 \mathrm{c}$ was by far the most effective in inhibiting the roots of I. grandifolia $72.8 \%$ ), followed by compounds $\mathbf{4 g}$ ' (58.2\% inhibition) and $\mathbf{4 h}$ ' (55.3\%). All the remaining compounds inhibited the development of the roots of $I$. grandifolia less than $50 \%$.

The compound $\mathbf{4 g}$ ' serendipitously emerged as the most potent inhibitor, showing moderate to high inhibition (38.6\% to $74.5 \%$ ) against all the species tested. Although a clear structure-activity relationship cannot be secured from these data, it is evident that the pyran ring is somehow associated with the activity. It may be concluded that presence of one less pyridone moiety in the molecule does not reduce the phytotoxicity, but rather increases it and that the presence of an aromatic ring at any position (closer or farther from the pyridone ring) encourages higher activity than an alkyl substituent.

\section{Experimental}

\subsection{General}

All the chemicals were purchased from Sigma Aldrich (Milwaukee, WI, USA) and used without purification. The ${ }^{1} \mathrm{H}$ - and ${ }^{13} \mathrm{C}-\mathrm{NMR}$ spectra were recorded on a Varian Mercury 300 instrument (300 $\mathrm{MHz}$ and $75 \mathrm{MHz}$ respectively), using deuterated DMSO as a solvent and tetramethylsilane (TMS) as internal standard $(\delta=0)$. IR spectra were obtained using a Perkin Elmer Paragon 1000 FTIR spectrophotometer, using potassium bromide $(1 \% \mathrm{v} / \mathrm{v})$ disks, scanning from 600 to $4000 \mathrm{~cm}^{-1}$. Lowresolution mass spectra were recorded on a Fisons Platform instrument under ESI conditions. Chemical ionisation accurate mass spectra were recorded on an Apex III FT-ICR-MS spectrometer with high resolution (resolution $=100,000$ FWHM). The lock used for calibration was chloropentafluorobenzene. Values quoted are reported as a ratio of mass to charge in Daltons. Melting points are uncorrected and were obtained from MQAPF-301 melting point apparatus (Microquimica, Brazil). Analytical thin layer chromatography analysis was conducted on aluminum backed precoated silica gel plates. Column chromatography was performed over silica gel (60-230 mesh).

\subsection{Synthesis}

\subsubsection{Synthesis of 4-hydroxy-6-methyl-2H-pyran-2-one (2)}

Dehydroacetic acid 1 ( $1 \mathrm{mmol})$ and $92 \%$ sulfuric acid aqueous solution $(5 \mathrm{mmol})$ were placed in a $25 \mathrm{~mL}$ flask and the mixture was heated to $130{ }^{\circ} \mathrm{C}$ for 10 minutes. While still warm, the mixture was poured into a beaker containing chopped ice. The resulting precipitate formed was filtered off and washed with cold water, leading to the isolation of 4-hydroxy-6-methylpyran-2-one (2) as a white solid in $86 \%$ yield. Mp $186.5-187.7^{\circ} \mathrm{C}$; IR: 3,440, 3,097, 2,962, 2,821, 2,733, 2,622, 1,717, 1,657, 1,626, $1,586,1,540,1,509,1,493,1,344,1,303,1,256,1,191,1,149,1,042,989,878,839,814,591,526$, and 
$498 \mathrm{~cm}^{-1} ;{ }^{1} \mathrm{H}-\mathrm{NMR}\left(\mathrm{DMSO}_{6}\right) \delta: 2.13\left(\mathrm{~d}, 3 \mathrm{H}, J=0.3 \mathrm{~Hz}, \mathrm{CH}_{3}\right), 5.19(\mathrm{~d}, 1 \mathrm{H}, J=2.1 \mathrm{~Hz}, \mathrm{H} 3), 5.93$ (m, 1H, H5 ), 11.58 (bs, 1H, OH); ${ }^{13} \mathrm{C}-\mathrm{NMR}\left(\mathrm{DMSO}_{\mathrm{d}}\right)$ ) $\delta: 20.1\left(6-\mathrm{CH}_{3}\right), 88.8(\mathrm{C} 3), 100.9(\mathrm{C} 5), 164.0$ (C6), 164.6 (C4), 171.2 (C2); MS, m/z (\%) $126\left(\mathrm{M}^{+}, 33\right), 111$ (15), 98 (70), 85 (33), 69 (100), 55 (25).

\subsubsection{Synthesis of 4-hydroxy-6-methylpyridin-2(1H)-one (3)}

4-Hydroxy-6-methylpyran-2-one (2, $1 \mathrm{mmol})$ and $28 \%$ ammonium hydroxide ( $5 \mathrm{mmol}$ ) were added under stirring to a $25 \mathrm{~mL}$ flask. The mixture was heated to $100{ }^{\circ} \mathrm{C}$ for $6 \mathrm{~h}$, after which it was cooled in an ice bath and the resultant white solid was filtered off and washed with cold water to provide 4-hydroxy-6-methylpyridin-2-one (3) in $80 \%$ yield; Mp > $300{ }^{\circ} \mathrm{C}$; IR: 3,445, 3,268, 3,091, 2,894, 2,796, 2,716, 1,653, 1,634, 1,603, 1,550, 1,400, 1,381, 1,352, 1,267, 1,232, 1,175, 1,042, 903, 842, 830, 627, 595, and $535 \mathrm{~cm}^{-1} ;{ }^{1} \mathrm{H}-\mathrm{NMR}\left(\mathrm{DMSO}_{6}\right) \delta: 2.06\left(\mathrm{~d}, 3 \mathrm{H}, J=0.3 \mathrm{~Hz}, 6-\mathrm{CH}_{3}\right), 5.32(\mathrm{~d}, 1 \mathrm{H}$, $J=2.1 \mathrm{~Hz}, \mathrm{H} 3), 5.58(\mathrm{~m}, 1 \mathrm{H}, \mathrm{H} 5), 10.97$ (bs, 1H, OH), 10.41 (bs, 1H, NH); ${ }^{13} \mathrm{C}-\mathrm{NMR}$ (DMSO-d 6 ): $\delta$ $19.1\left(6-\mathrm{CH}_{3}\right), 96.4$ (C3), 99.0 (C5), 146.6 (C6), 165.53 (C2), 168.3 (C4); MS, m/z (\%) $125\left(\mathrm{M}^{+}, 77\right)$, 96 (22), 84 (100), 69 (17), 68 (17), 55 (16).

\subsubsection{General method of preparation of bis(pyridyl)methanes 4a-h}

To a $100 \mathrm{~mL}$ round-bottomed flask, 95\% ethanol $(20 \mathrm{~mL})$, methanol (20 mL), 4-hydroxy-6methylpyridin-2-one $(3,1.5 \mathrm{mmol})$, piperidine $(15 \mu \mathrm{L})$ and pyridine $(45 \mu \mathrm{L})$ were added. The reaction mixture was kept under stirring for 5 minutes at $25{ }^{\circ} \mathrm{C}$. The corresponding aldehyde $(1 \mathrm{mmol})$ was added and the mixture kept under reflux. On completion of the reaction, as determined by TLC analysis, the volume of solvent was reduced under reduced pressure in a rotatory evaporator and the precipitate formed was filtered and washed with methanol, followed by ethyl ether. This led to the formation of 4a-h in high purity, without need of any further purification.

3,3'-Methylenebis(4-hydroxy-6-methylpyridin-2(1H)-one) (4a). Reflux $1.5 \mathrm{~h}$, White solid; yield: 92\%; $\mathrm{Mp}>300^{\circ} \mathrm{C}$; IR: 3,445, 3,284, 3,059, 3,023, 2,899, 2,644, 1,640, 1,568, 1,442, 1,389, 1,368, 1,267, $1,196,1,132,910,835,805,611$, and $546 \mathrm{~cm}^{-1} ;{ }^{1} \mathrm{H}-\mathrm{NMR}\left(\mathrm{DMSO}_{6}\right) \delta: 2.10\left(\mathrm{~s}, 6 \mathrm{H}, 6-\mathrm{CH}_{3}\right.$ and 6'- $\left.\mathrm{CH}_{3}\right), 3.41$ (s, 2H, H7), 5.86 (s, 2H, H5 and H5'), 11.74 (s, 2H, H1 and H1'), 12.11 (bs, 1H, 4-OH

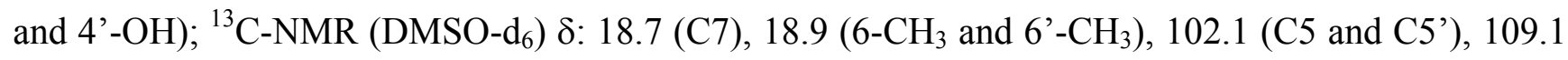
(C3 and C3'), 144.3 (C6 and C6'), 165.6 (C2 and C2'), 167.0 (C4 and C4'); HRMS (ESI TOF-MS): Calcd. for $\mathrm{C}_{13} \mathrm{H}_{14} \mathrm{~N}_{2} \mathrm{O}_{4}$ 262.0954; found: 262.0951 .

3,3'-(Ethane-1,1-diyl)bis(4-hydroxy-6-methylpyridin-2(1H)-one) (4b). Reflux $90 \mathrm{~h}$, White solid; yield: 35\%; Mp > $300{ }^{\circ} \mathrm{C}$; IR: 3,446, 3,264, 2,891, 2,610, 1,644, 1,558, 1,451, 1,390, 1,335, 1,265, 1,198, $1,165,915,816,641$, and $553 \mathrm{~cm}^{-1}$; ${ }^{1} \mathrm{H}-\mathrm{NMR}\left(\mathrm{DMSO}_{\mathrm{d}}\right) \mathrm{\text { }}$ ) $\delta: 1.58$ (d, 3H, $\left.J=7.5 \mathrm{~Hz}, \mathrm{H} 8\right), 2.09$ (s, 6H, 6- $\mathrm{CH}_{3}$ and 6' $-\mathrm{CH}_{3}$ ), 4.49 (q, 1H, $\left.J=7.5 \mathrm{~Hz}, \mathrm{H} 7\right), 5.81$ (s, 2H, H5 and H5'), 11.63 (s, 2H, H1 and H1');

${ }^{13} \mathrm{C}-\mathrm{NMR}\left(\mathrm{DMSO}-\mathrm{d}_{6}\right)$ 8: $15.3(\mathrm{C} 8), 18.7\left(6-\mathrm{CH}_{3}\right.$ and 6'- $\left.\mathrm{CH}_{3}\right), 25.3(\mathrm{C} 7), 102.7$ (C5 and C5'), 112.9 (C3 and C3'), 144.0 (C6 and C6'), 166.5 (C2 and C2'), 166.7 (C4 and C4'); HRMS (ESI TOF-MS): Calcd. for $\mathrm{C}_{14} \mathrm{H}_{16} \mathrm{~N}_{2} \mathrm{O}_{4} 276.1110$; found: 276.1110 . 
3,3'-(Propane-1,1-diyl)bis(4-hydroxy-6-methylpyiridin-2(1H)-one) (4c). Reflux $90 \mathrm{~h}$, White solid; yield $56 \%$; $\mathrm{Mp}>300{ }^{\circ} \mathrm{C}$; IR: 3,447, 3,057, 2,955, 2,872, 2,622, 1,637, 1,460, 1,393, 1,361, 1,265, $1,252,1,193,835,817,624$, and $557 \mathrm{~cm}^{-1} ;{ }^{1} \mathrm{H}-\mathrm{NMR}\left(\mathrm{DMSO}_{\mathrm{d}}\right) \delta: 0.73$ (t, 3H, $J=7.2 \mathrm{~Hz}, \mathrm{CH}_{3}$ ), 2.03 $2.20\left(\mathrm{~m}, 8 \mathrm{H}, \mathrm{H} 8,6-\mathrm{CH}_{3}\right.$ and 6' $\left.-\mathrm{CH}_{3}\right), 4.18(\mathrm{t}, 1 \mathrm{H}, J=8.1 \mathrm{~Hz}, \mathrm{H} 7), 5.81$ (s, 2H, H5 and H5'), 11.60 (s,

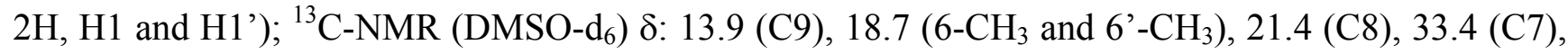
102.7 (C5 and C5'), 111.6 (C3 and C3'), 144.2 (C6 and C6'), 166.1 (C2 and C2'), 166.2 (C4 and C4'); HRMS (ESI TOF-MS): Calcd. for $\mathrm{C}_{15} \mathrm{H}_{18} \mathrm{~N}_{2} \mathrm{O}_{4}$ 290.1267; found: 290.1263 .

3,3'-(Phenylmethylene)bis(4-hydroxy-6-methylpyridin-2(1H)-one) (4e). Reflux $40 \mathrm{~h}$, White solid; yield: 56\%; $\mathrm{Mp}>300{ }^{\circ} \mathrm{C}$; IR: 3,445, 3,280, 3,062, 2,898, 1,632, 1,453, 1,394, 1,361, 1,284, 1,192, 924, 817, 772, and $583 \mathrm{~cm}^{-1} ;{ }^{1} \mathrm{H}-\mathrm{NMR}\left(\mathrm{DMSO}_{\mathrm{d}}\right) \mathrm{f}$ : $2.15\left(\mathrm{~s}, 6 \mathrm{H}, 6-\mathrm{CH}_{3}\right.$ and 6'- $\left.\mathrm{CH}_{3}\right), 5.87$ (bs, 3H, H7, H5 and H5'), 6.99 (d, 2H, $J=7.5 \mathrm{~Hz}, \mathrm{H} 2$ " and H6"), 7.12 (t, 1H, $J_{1}=J_{2}=7.5 \mathrm{~Hz}, \mathrm{H} 4$ "), 7.20 (t, 2H, $J=7.5 \mathrm{~Hz}, \mathrm{H} 3$ " and H5"), 11.69 (s, 2H, H1 and H1'), 12.31 (bs, 1H, 4-OH and 4'-OH); ${ }^{13} \mathrm{C}-\mathrm{NMR}$ (75

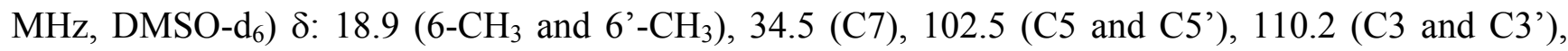
126.0 (C4”), 126.9 (C2" and C6”), 128.5 (C3" and C5”), 139.6 (C1”), 144.8 (C6 and C6'), 167.7 (C2 and C2'), 167.5 (C4 and C4'); HRMS (ESI TOF-MS): Calcd. for $\mathrm{C}_{19} \mathrm{H}_{18} \mathrm{~N}_{2} \mathrm{O}_{4}$ 338.1267; found: 338.1265 .

3,3'-(3-Phenylpropane-1,1-diyl)bis(4-hydroxy-6-methylpyridin-2(1H)-one) (4f). Reflux $120 \mathrm{~h}$, White solid; yield 75\%; Mp 292.5-293.4 ${ }^{\circ} \mathrm{C}$; IR: 3,446, 3,284, 3,058, 3,042, 3,024, 2,905, 2,622, 1,635, 1,559, 1,455, 1,437, 1,396, 1,257, 1,177, 816, 697, and $552 \mathrm{~cm}^{-1} ;{ }^{1} \mathrm{H}-\mathrm{NMR}\left(\mathrm{DMSO}_{6}\right)$ ) 2.10 (s, 6H, 6- $\mathrm{CH}_{3}$ and 6' $\left.-\mathrm{CH}_{3}\right), 2.4(\mathrm{~m}, 2 \mathrm{H}, \mathrm{H} 8), 2.48$ (m, 2H, H9), 4.31 (t, 1H, J= 7.5 Hz, H7), 5.83 (s, 2H, H5 and H5'), 7.06-7.24 (m, 5H, H2", H3", H4", H5" and H6"), 11.65 (s, 2H, NH-1 and NH-1'), 11.86 (s, 2H, 4-OH and 4'-OH); ${ }^{13} \mathrm{C}-\mathrm{NMR}\left(\mathrm{DMSO}^{-} \mathrm{d}_{6}\right) \delta$ : $18.8\left(6-\mathrm{CH}_{3}\right.$ and 6'- $\left.\mathrm{CH}_{3}\right), 30.7$ (C8), 30.8 (C7), 35.0 (C9), 102.7 (C5 and C5'), 111.5 (C3 and C3'), 126.3 (C4”), 128.9 (C3" and C5"), 129.0 (C2" and C6”), 137.5 (C1'), 142.5 (C6 and C6'), 167.1 (C2 and C2'), 167.2 (C4 and C4'); HRMS (ESI') $\mathrm{C}_{21} \mathrm{H}_{22} \mathrm{~N}_{2} \mathrm{NaO}_{4}\left(\mathrm{MNa}^{+}\right)$required 389.1472, found 389.1479.

(土)-2-(4-Hydroxy-6-methyl-2-oxo-1,2-dihydropyridin-3-yl)-7-methyl-4-phenyl-3,4-dihydro-2Hpyrano-[3,2-c]pyridin-5(6H)-one (4g'). Reflux $140 \mathrm{~h}$, White solid; yield 57\%; Mp 254.8-255.6 ${ }^{\circ} \mathrm{C}$; IR: 3,418, 3,132, 3,058, 2,932, 1,616, 1,579, 1,455, 1,390, 1,363, 1,321, 1,260, 1,181, 1,155, 1,113, 1,039, 971, 872, 821, 765, 701, 663, and $598 \mathrm{~cm}^{-1} ;{ }^{1} \mathrm{H}-\mathrm{NMR}\left(\mathrm{DMSO}-\mathrm{d}_{6}\right) \delta: 1.66(\mathrm{~d}, 1 \mathrm{H}, J=13.8 \mathrm{~Hz}$, $\mathrm{H} 8), 2.02\left(\mathrm{~s}, 3 \mathrm{H}, 6-\mathrm{CH}_{3}\right), 2.09$ (s, 3H, 6'- $\left.-\mathrm{CH}_{3}\right), 3.10$ (dt, 1H, $\left.J=13.8,4.8 \mathrm{~Hz}, \mathrm{H} 8^{\prime}\right), 4.01$ (d, 1H, $J=$ $4.8 \mathrm{~Hz}, \mathrm{H} 7), 5.12$ (dd, 1H, $J=12.3,1.8 \mathrm{~Hz}, \mathrm{H} 9), 5.62$ (s, 1H, H5), 5.65 (s, 1H, H5'), 7.08 (d, 2H, $J=$ $7.2 \mathrm{~Hz}, \mathrm{H} 2$ " and H6"), 7.16 (t, 1H, $J=7.2 \mathrm{~Hz}, \mathrm{H} 4$ "), 7.26 (t, 2H, J= 7.2 Hz, H3" and H5"), 10.44 (s, $\left.1 \mathrm{H}, 4^{\prime}-\mathrm{OH}\right) ; 11.02$ (s, 2H, NH-1 and NH-1'); ${ }^{13} \mathrm{C}-\mathrm{NMR}\left(\mathrm{DMSO}_{6}\right) \delta$ : $19.0\left(6-\mathrm{CH}_{3}\right), 19.1\left(6^{\prime}-\mathrm{CH}_{3}\right)$, 32.5 (C8), 35.4 (C7), 67.2 (C9), 98.5 (C5), 98.7 (C5'), 104.6 (C3), 105.5 (C3'), 126.4 (C4”), 128.6 (C2" and C6"), 128.7 (C3" and C5"), 143.8 (C1"), 146.4 (C6 and C6'), 164.0 (C2), 164.3 (C2'), 164.9 (C4), 166.4 (C4'); HRMS (ESI $\left.{ }^{+}\right) \mathrm{C}_{21} \mathrm{H}_{20} \mathrm{~N}_{2} \mathrm{NaO}_{4}\left(\mathrm{MNa}^{+}\right)$required 387.1315, found 387.1301.

( \pm )-3,7-Dimethyl-2-phenyl-2H-pyrano[3,2-c]pyridin-5(6H)-one (4h'). Reflux $190 \mathrm{~h}$, White solid; yield 49\%; Mp 222.4-223.3 ${ }^{\circ} \mathrm{C}$; IR: 3,446, 3,058, 2,963, 2,897, 2,746, 1,669, 1,647, 1,630, 1,601, 1,565, 
$1,485,1,453,1,394,1,263,1,251,1,145,1,035,951,907,869,803,770,763,696,663,649,627$, and $539 \mathrm{~cm}^{-1} ;{ }^{1} \mathrm{H}-\mathrm{NMR}\left(\mathrm{DMSO}_{6}\right) \delta: 1.61\left(\mathrm{~s}, 3 \mathrm{H}, 8-\mathrm{CH}_{3}\right), 2.04\left(\mathrm{~s}, 3 \mathrm{H}, 6-\mathrm{CH}_{3}\right), 5.59(\mathrm{~s}, 1 \mathrm{H}, \mathrm{H} 5), 5.77$ (s, 1H, H7), 6.40 (s, 1H, H9), 7.33-7.37 (m, 5H, H2', H3', H4', H5' and H6'), 11.20 (s, 1H, NH-1); ${ }^{13} \mathrm{C}-$ NMR (DMSO-d 6 ) 8: $19.2\left(6-\mathrm{CH}_{3}\right), 20.0\left(8-\mathrm{CH}_{3}\right), 81.0$ (C7), 98.0 (C5), 104.4 (C3), 114.5 (C9), 127.0 (C8), 128.1 (C2' and C6'), 129.4 (C3' and C5'), 129.5 (C4'), 139.5 (C1'), 145.6 (C6), 160.2 (C2), 161.3 (C4); HRMS (ESI $\left.{ }^{+}\right) \mathrm{C}_{16} \mathrm{H}_{15} \mathrm{NNaO}_{2}\left(\mathrm{MNa}^{+}\right)$required 276.0995, found 276.0995.

\subsubsection{Single crystal structure determination}

The crystal structures of $\mathbf{4 f}, \mathbf{4} \mathbf{g}$ ' and $\mathbf{4 h}$ ' were determined from single crystal X-ray diffraction data collected at $150 \mathrm{~K}$ with an Oxford Cryosystems Cryostream N2 open-flow cooling device [27]. Data were collected using an Enraf-Nonius KappaCCD diffractometer (Mo-Ka radiation $(\lambda=0.71073 \AA$ ) and processed using the DENZO-SMN package [28], including inter-frame scaling (which was carried out using SCALEPACK within DENZO-SMN). The structures were solved using SIR92 [29]. Refinement was carried out using full-matrix least-squares within the CRYSTALS suite [30] on $\mathrm{F}^{2}$. A small amount of disorder was present in $\mathbf{4 f}$ (alkyl bridge) and 4g' (disordered DMSO) which was modeled as detailed in the supplementary information (CIF). Refinement results are included in Table 3 and full crystallographic data have also been deposited with the Cambridge Crystallographic Data Centre, CCDC 755517 - 755519. Copies of these data can be obtained free of charge from The Cambridge Crystallographic Data Centre via www.ccdc.cam.ac.uk/data_request/cif.

Table 3. Crystal data and structure refinements for compounds $\mathbf{4 f}, \mathbf{4 g}$ ' and $\mathbf{4 h}$ '.

\begin{tabular}{|c|c|c|c|}
\hline & $\underline{\mathbf{4 f}}$ & $\underline{4 g}$ & $\underline{4 h}$ ' \\
\hline Chemical Formula & $\mathrm{C}_{21} \mathrm{H}_{22} \mathrm{~N}_{2} \mathrm{O}_{4}$ & $\mathrm{C}_{21} \mathrm{H}_{20} \mathrm{~N}_{2} \mathrm{O}_{4} \cdot 0.421\left(\mathrm{C}_{2} \mathrm{H}_{6} \mathrm{OS}\right)$ & $\mathrm{C}_{16} \mathrm{H}_{15} \mathrm{NO}_{2}$ \\
\hline $\mathrm{FW}$ & 366.41 & 396.98 & 253.11 \\
\hline $\begin{array}{l}\text { Crystal system / Space } \\
\text { group }\end{array}$ & $C 2 / c$ & $P 2_{1} / n$ & $P 2{ }_{1} / c$ \\
\hline Crystal colour & Colourless & Colourless & Colourless \\
\hline Crystal size (mm) & $0.22 \times 0.16 \times 0.12$ & $0.20 \times 0.18 \times 0.18$ & $0.60 \times 0.06 \times 0.04$ \\
\hline $\mathrm{a}(\AA)$ & 21.8480 & 20.9365 & 13.8876 \\
\hline $\mathrm{b}(\AA)$ & 12.1257 & 9.85390 & 5.7745 \\
\hline c $(\AA)$ & 16.7405 & 21.4160 & 16.4267 \\
\hline$\alpha\left(^{\circ}\right)$ & 90.000 & 90.000 & 90.000 \\
\hline$\beta\left(^{\circ}\right)$ & 121.6650 & 113.2622 & 104.791 \\
\hline$\gamma\left({ }^{\circ}\right)$ & 90.000 & 90.000 & 90.000 \\
\hline$V\left(\AA^{3}\right)$ & 3774.71 & 4059.08 & 1273.67 \\
\hline $\mathrm{Z}$ & 8 & 8 & 4 \\
\hline $\mathrm{D}_{\text {calc }}\left(\mathrm{g} / \mathrm{cm}^{3}\right)$ & 1.289 & 1.300 & 1.321 \\
\hline$T(\mathrm{~K})$ & 150 & 150 & 150 \\
\hline$\mu(\mathrm{Mo} \mathrm{K} \alpha)\left(\mathrm{mm}^{-1}\right)$ & 0.09 & 0.13 & 0.09 \\
\hline Reflections collected $\left(R_{i n t}\right)$ & $4264(0.0289)$ & $9268(0.025)$ & $2923(0.030)$ \\
\hline $\begin{array}{l}\text { Data/Restraints/ } \\
\text { Parameters }\end{array}$ & $2471 / 0 / 254$ & $9247 / 60 / 552$ & $2130 / 0 / 173$ \\
\hline$R_{1}(I>2 \sigma(I))$ & 0.059 & 0.084 & 0.050 \\
\hline$R_{1} / w R_{2}$ (all data) & 0.142 & 0.123 & 0.079 \\
\hline
\end{tabular}




\subsection{Plant growth inhibition assays}

In order to evaluate the growth regulatory potential of the synthesized bis(pyridyl)methanes (4a-h), two different bioassays were carried out.

\subsubsection{Radicle elongation assay on filter paper}

The solutions of bis(pyridyl)methanes $\mathbf{4 a}-\mathbf{h}$ were prepared by dissolving the compounds in dimethylsufoxide $(150 \mu \mathrm{L})$. After addition of the surfactant Tween $80(72 \mu \mathrm{L})$, the resulting suspension was transferred to a volumetric flask and diluted with water to $50 \mathrm{~mL}$, to obtain the final concentration $5 \times 10^{-4} \mathrm{~mol} \mathrm{~L}^{-1}$. These suspensions were sonicated for $5 \mathrm{~min}$, resulting in complete dissolution of the test compound. Then $4 \mathrm{~mL}$ aliquots were used to imbibe two sheets of filter paper (Whatman $\mathrm{n}^{\mathrm{o}}$ 1) placed in $100 \times 15 \mathrm{~mm}$ glass Petri dishes. To each dish were added 20 seeds of Sorghum bicolor L. Moench (Geneze Company, Paracatu, Minas Gerais State, Brazil) or Cucumis sativus L. (purchased from a local market). The plates were incubated at $25^{\circ} \mathrm{C}$ under fluorescent light $(8 \times 40 \mathrm{~W})$ for $72 \mathrm{~h}$. Radicle length was then measured, and total germination recorded. Seeds were considered to have germinated if a radicle protruded at least $1 \mathrm{~mm}$. Treatments were carried out in a completely randomized design with five replications. The data, expressed as percentage of radical growth inhibition with respect to untreated controls, were analyzed using Tukey's test at 0.05 probability level.

\subsubsection{Greenhouse trials}

Plastic pots $(0.13 \mathrm{~L})$ were filled with acid-washed sand, which was saturated with the solution of the test compound $\left(60 \mathrm{~mL} / 450 \mathrm{~g}\right.$ of sand, corresponding to $6.7 \times 10^{-8} \mathrm{~mol}$ a.i./g substrate). Four seeds of Ipomoea grandifolia, C. sativus or S. bicolor were placed in each pot. Seedlings were grown in a greenhouse, and watered as required with tap water or, twice a week, with half-strength Hoagland solution, to maintain the humidity at $13.3 \% \mathrm{w} / \mathrm{w}$. Twenty-one days after sowing, plants were harvested, and the roots and aerial parts were separated and weighted. Tissues were then dried at $60{ }^{\circ} \mathrm{C}$ until there was no further weight loss, and the corresponding dry mass was determined. The percentage of root and aerial part growth inhibition was calculated in relation to the mass of the respective control. Data were expressed and analyzed as previously described [31].

\section{Conclusions}

We have described the preparation of a variety of functionalized bis(pyridyl)methanes, starting from dehydroacetic acid. We have demonstrated that the condensation of 4-hydroxypyridone 3 with cinnamaldehydes results in the formation of pyran derivatives. In addition, we have described the effect of the pyridone derivatives prepared on the aerial parts and on the radicle growth of the dicotyledonous species Ipomoea grandifolia and Cucumis sativus and the monocotyledonous species Sorghum bicolor. In general the compounds showed some phytotoxic selectivity, being more active against the dicotyledonous species. It was observed that all tested compounds inhibited the development of the roots of $C$. sativus by more than $50 \%$ and three of them inhibit the development of the aerial parts of I. grandifolia by more than 50\%. Although no concrete structure-activity 
relationship analysis could be derived due to the limited number of compounds prepared, the phytotoxicity reported for this class of bis(pyridyl)methane substances is an indication of the potential of these substances as lead structures for the development of new compounds with increased activity. Work is currently underway to achieve this goal.

\section{Acknowledgements}

We are grateful to the following Brazilian agencies: CNPq (Conselho Nacional de Desenvolvimento Científico e Tecnológico) for financial support and research fellowships (AJD, LCAB) and FAPEMIG (Fundação de Amparo à Pesquisa do Estado de Minas Gerais) for financial support and a student fellowship (VMMV). We also thank the Indian trusts: Narotam Sekhsaria Foundation and J. N. Tata Endowment for financial support (AHR).

\section{References and Notes}

1. Öztürk, G.; Erol, D.D.; Uzbay, T; Aytemir, M.D. Synthesis of 4(1H)-pyridinone derivatives and investigation of analgesic and antiinflammatory activities. Farmaco 2001, 56, 251-256.

2. Findlay, J.A.; Tam, W.H.J.; Krepinsky, J. The chemistry of some 6-methyl-4-hydroxy-2pyridones. Can. J. Chem. 1978, 56, 613-616.

3. Abadi, A.; Al-Deeb, O.; Al-Afify, A.; El-Kashef, H. Synthesis of 4-alkyl (aryl)-6-aryl-3-cyano2(1H)-pyridinones and their 2-imino isosteres as nonsteroidal cardiotonic agents. Farmaco 1999, 54, 195-201.

4. Storck, P.; Aubertin, A.; Grierson, D.S. Tosylation/mesylation of 4-hydroxy-3-nitro-2pyridinones as an activation step in the construction of dihydropyrido[3,4b]benzo[f][1,4]thiazepin-1-one based anti-HIV agents. Tetrahedron Lett. 2005, 46, 2919-2922.

5. Macdonald, G.E.; Puri, A.; Shillinget, D.G. Interactive effect of photoperiod and fluridone on growth, reproduction, and biochemistry of dioecious hydrilla (Hydrilla verticillata). Weed Sci. 2008, 56, 189-195.

6. Wakabayashi, K.; Böger, P. Phytotoxic sites of action for molecular design of modern herbicides (Part 2): Amino acid, lipid and cell wall biosynthesis, and other targets for future herbicides. Weed Biol. Manag. 2004, 4, 59-70.

7. Evidente, A.; Fiore, M.; Bruno, G.; Sparapano, L.; Motta, A. Chemical and biological characterisation of sapinopyridione, a phytotoxic 3,3,6-trisubstituted-2,4-pyridione produced by Sphaeropsis sapinea, a toxigenic pathogen of native and exotic conifers, and its derivatives. Phytochemistry 2006, 67, 1019-1028.

8. Cocco, M.T.; Congiu, C.; Onnis, V. Synthesis and antitumour activity of 4-hydroxy-2-pyridone derivatives. Eur. J. Med. Chem. 2000, 35, 545-552.

9. Cocco, M.T.; Congiu, C.; Onnis, V. New bis(pyridyl)methane derivatives from 4-hydroxy-2pyridones: synthesis and antitumoral activity. Eur. J. Med. Chem. 2003, 38, 37-47.

10. Torres, M.; Gil, S.; Parra, M. New synthetic methods to 2-Pyridone rings. Curr. Org. Chem. 2005, 9, 1757-1780.

11. Jauasinghe, L.; Abbas, H.K.; Jacob, M.R.; Herath, W.H.M.W.; Nanayakkara, N.P.D. N-Methyl-4hydroxy-2-pyridinone Analogues from Fusarium oxysporum. J. Nat. Prod. 2006, 69, 439-442. 
12. Devi, N.S.; Perumal, S. A facile four-component tandem protocol for the synthesis of novel 2,6diaryl-2,3-dihydro-1H-pyridin-4-ones. Tetrahedron Lett. 2007, 48, 5627-5629.

13. Pei, L.X.; Huang, S.L.; Shen, Y.D.; An, L.Q.; Huang, Z.S. Li, Y.M.; Gu, L.Q.; Bu, X.Z.; Chan, A.S.C. Synthesis of novel dihydrofuro[b]-pyridinone derivatives: Oxidation coupling of 3hydroxy-4(1H)-pyridinone with $\beta$-dicarbonyl compounds. Tetrahedron Lett. 2005, 46, 5085-5088.

14. Barbosa, L.C.A.; Demuner, A.J.; Maltha, C.R.A.; Teixeira, R.R.; Souza, K.A.P.; Bicalho, K.U. Phytogrowth activity of 3-(3-chlorobenzyl)-5-arylidenofuran-2(5H)-ones. Z. Naturforsch. Sect. B 2009, 64, 245-251.

15. Barbosa, L.C.A.; Nogueira, L.B.; Maltha, C.R.A.; Teixeira, R.R.; Silva, A.A. Synthesis and phytogrowth properties of oxabicyclic analogues related to helminthosporin. Molecules 2009, 14, $160-173$.

16. Barbosa, L.C.A.; Teixeira, R.R.; Forlani, G.; Veloso, D.P.; Carneiro, J.W.M. Synthesis of photosynthesis-inhibiting nostoclide analogues. J. Agric. Food Chem. 2008, 56, 2321-2328.

17. Barbosa, L.C.A.; Rocha, M.E.; Teixeira, R.R.; Maltha, C.R.A.; Forlani, G. Synthesis of 3-(4bromobenzyl)-5-(aryl methylene)-5H-furan-2-ones and their activity as inhibitors of the photosynthetic electron transport chain. J. Agric. Food Chem. 2007, 55, 8562-8569.

18. Barbosa, L.C.A.; Costa, A.V.; Demuner, A.J.; Silva, A.A. Synthesis and herbicidal activity of

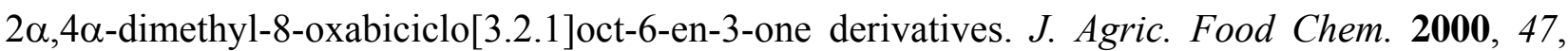
4807-4814.

19. Lima, L.S.; Barbosa, L.C.A.; Alvarenga, E.S.; Demuner, A.J.; Silva, A.A. Synthesis and phytotoxicity evaluation of substituted para-benzoquinones. Aust. J. Chem. 2003, 36, 625-630.

20. Alvarenga, E.S.; Barbosa, L.C.A.; Saliba, W.A.; Arantes, F.F.P.; Demuner, A.J.; SILVA, A.A. Síntese e avaliação da atividade fitotóxica de derivados da $\alpha$-santonina. Quím. Nova 2009, 32, 401-406.

21. Barbosa, L.C.A; Ferreira, M.L.; Demuner, A.J.; Silva, A.A.; Pereira, R.C. Preparation and phytotoxicity of sorgoleone analogues. Quím. Nova 2001, 24, 751-755.

22. Costa, A.V.; Barbosa, L.C.A.; Demuner, A.J.; Silva, A.A. Synthesis and Herbicidal activity of

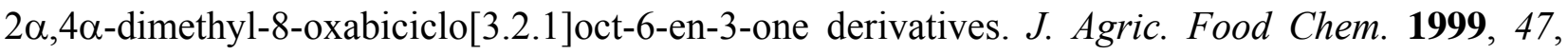
4807-4814.

23. Barbosa, L.C.A; Chaves, F.C.; Demuner, A.J.; Silva, A.A. Synthesis of new helminthosporal analogues with plant-growth regulatory properties via oxyallyl cation. Z. Naturforsch. Sect. B 2006, 61, 1287-1291.

24. Barbosa, L.C.A; Demuner, A.J.; Maltha, C.R.A.; Silva, P.S. Síntese e avaliação da atividade fitotóxica de novos análogos oxigenados do ácido helmintospórico. Quím. Nova 2003, 26, $655-660$.

25. Findlay, J.A.; Krepinsky, J.; Shum, F.Y.; Tam, W.H.J. Reactions of 4-hydroxy-6-methyl-2pyridone with aldehydes. Can. J. Chem. 1976, 54, 270-274.

26. Lee Y.R.; Kweon, H.; Koh, W.S.; Min, K.R.; Kim, Y.; Lee, S.H. One-Pot Preparation of pyranoquinolinones by ytterbium(III) trifluoromethanesulfonate-catalyzed reactions: Efficient synthesis of flindersine, N-methylflindersine, and zanthosimuline natural products. Synthesis 2001, 12, 1851-1855. 
27. Cosier, J.; Glazer, A.M. A nitrogen-gas-stream cryostat for general X-ray diffraction studies. $J$. Appl. Cryst. 1986, 19, 105-107.

28. Otwinowski, Z.; Minor, W. In Methods in Enzymology; Carter, C.W., Jr., Sweet, R.M., Eds.; Academic Press: New York, NY, USA, 1997; Vol. 276, p. 307.

29. Altomare, A.; Cascarano, G.; Giacovazzo, G.; Guagliardi, A.; Burla, M.C.; Polidori, G.; Camalli, M. SIRPOW.92-A program for automatic solution of crystal structures by direct methods optimized for powder data. J. Appl. Cryst. 1994, 27, 435-436.

30. Betteridge, P.W.; Carruthers, J.R.; Cooper, G.I.; Prout, C.K.; Watkin, D.J. CRYSTALS version 12: Software for guided crystal structure analysis. J. Appl. Cryst. 2003, 36, 1487-1487.

31. Dias, L.C.; Demuner, A.J.; Valente, V.M.M.; Barbosa, L.C.A.; Martins, F.T.; Dorigueto, A.C.; Ellena, J. Preparation of achiral and chiral E-enaminopyran-2,4-diones and their phytotoxic activity. J. Agric. Food Chem. 2009, 57, 1399-1405.

Sample Availability: Samples of the compounds $\mathbf{4 a}, \mathbf{4 b}, \mathbf{4 c}, \mathbf{4 e}, \mathbf{4 f}, \mathbf{4 g}$ ' and $\mathbf{4 h}$ ' are available from the authors.

(C) 2009 by the authors; licensee Molecular Diversity Preservation International, Basel, Switzerland. This article is an open-access article distributed under the terms and conditions of the Creative Commons Attribution license (http://creativecommons.org/licenses/by/3.0/). 